\title{
Specific binding of perhydrohistrionicotoxin to Torpedo acetylcholine receptor
}

(reconstitution/local anesthetics/cholinergic receptor/ion translocation/ $\alpha$-bungarotoxin sites)

\author{
Janet Elliott, Susan M. J. Dunn, Steven G. Blanchard, and Michael A. Raftery
}

Church Laboratory of Chemical Biology, Division of Chemistry and Chemical Engineering, California Institute of Technology, Pasadena, California 91125

Communicated by James F. Bonner, February 28, 1979

\begin{abstract}
Torpedo californica postsynaptic membrane fragments were treated with base, which resulted in membranes that were depleted of many nonacetylcholine receptor polypeptides and contained acetylcholine receptor subunits of $\boldsymbol{M}_{\mathbf{r}}$ $40,000,50,000,60,000$, and 65,000 (Raftery, M. A., Vandlen, R. L., Reed, K. L. \& Lee, T. (1975) Cold Spring Harbor Symp. Quant. Biol. 40, 193-202). A 43,000-Mr polypeptide and some other components were quantitatively extracted. Base-treated membranes retained the capacity to bind $\left.{ }^{3} \mathrm{H}\right]$ perhydrohistrionicotoxin and the local anesthetics dibucaine and tetracaine. The regulation of this binding by carbamylcholine, as well as the kinetic mechanism of perhydrohistrionicotoxin binding, was unchanged. $\left[{ }^{3} \mathrm{H}\right]$ Perhydrohistrionicotoxin binding activity was largely reconstituted from $2 \%$ sodium cholate extracts of base-treated membranes. Therefore, the perhydrohistrionicotoxin binding site appears to be located on one or more of the acetylcholine receptor polypeptides, and the reconstitution of that binding site from detergent extracts does not require the presence of a $43,000-M_{\mathrm{r}}$ polypeptide.
\end{abstract}

Electrophysiological and biochemical evidence has been presented that suggests that perhydrohistrionicotoxin $\left(\mathrm{H}_{12}\right.$ - $\left.\mathrm{HTX}\right)$ interacts with or exerts control over the ion translocation mechanism(s) of the nicotinic acetylcholine receptor (AcChoR) of the postsynaptic membrane of the neuromuscular junction (1-4). We have shown (5) that a radiolabeled derivative, $\left[{ }^{3} \mathrm{H}\right] \mathrm{H}_{12}-\mathrm{HTX}$, binds to AcChoR-enriched membrane fragments from Torpedo californica in a ratio of $1 \mathrm{~mol}$ of $\left[{ }^{3} \mathrm{H}\right]-$ $\mathrm{H}_{12}$-HTX bound per $4 \mathrm{~mol}$ bound of ${ }^{125}$ I-labeled $\alpha$-bungarotoxin $(\alpha-\mathrm{BuTx})$ with a dissociation constant of $\approx 0.5 \mu \mathrm{M}$. The $\mathrm{H}_{12}$-HTX site, though distinct, is conformationally linked to the acetylcholine (AcCho) recognition site, because histrionicotoxin has been shown to increase the affinity of membranebound AcChoR for $\left[{ }^{3} \mathrm{H}\right] \mathrm{AcCho}(4)$ and conversely carbamylcholine (Carb) was found to increase the affinity of the membranes for $\left[{ }^{3} \mathrm{H}\right] \mathrm{H}_{12}-\mathrm{HTX}$ (5). It has been suggested that the transition to a state of increased affinity for agonists measured by biochemical procedures in vitro is analogous to "desensitization" in vivo, and that $\mathrm{H}_{12}$ - $\mathrm{HTX}$ acts to block conduction by converting the AcChoR to a "desensitized" state $(4,6)$. However, we found that $\mathrm{H}_{12}-\mathrm{HTX}$ at a concentration 10 -fold greater than its $K_{d}$ did not affect the rates of interconversion between the conformational states of the membrane-bound AcChoR from Torpedo californica-i.e., states of low and high affinity for agonists (5). The kinetic evidence of Schimerlik et al. (7) supports the notion that the final receptor conformations induced by cholinergic agonists on the one hand and by $\mathrm{H}_{12}-\mathrm{HTX}$ on the other are different. Another possible mechanism of action is a direct blockage of the ion channel when the channel is in a conducting state $(1,2)$.

A great deal of recent effort has focused on the identification

The publication costs of this article were defrayed in part by page charge payment. This article must therefore be hereby marked "advertisement" in accordance with 18 U. S. C. $\$ 1734$ solely to indicate this fact. of the $\mathrm{H}_{12}$-HTX binding site. The AcChoR from Torpedo californica purified by affinity chromatography in the detergent Triton X-100 (8) has been shown to bind AcCho and various cholinergic ligands (9-11). However, specific $\left[{ }^{3} \mathrm{H}\right] \mathrm{H}_{12}$ - $\mathrm{HTX}$ binding could not be detected in Triton extracts of membrane fragments (5). Sobel et al. (12) reported that histrionicotoxin binding could be recovered in the precipitate from Triton $\mathrm{X}$ 100/Berol 043 extracts of Torpedo marmorata membrane fragments and that this binding activity was associated with a polypeptide of $43,000 M_{\mathrm{r}}$. In contrast, Eldefrawi et al. (13) chromatographed a Triton extract of Torpedo ocellata membranes on a Sephadex G-200 column and reported a $\left[{ }^{3} \mathrm{H}_{3} \mathrm{H}_{12-}\right.$ HTX binding activity that was separated from $\left[{ }^{3} \mathrm{H}\right]$ AcCho binding activity. However, this solubilized binding component was not shown to be a protein, nor was binding demonstrated to be specific.

It was recently reported by Neubig et al. (14) that AcChoR-enriched membranes from Torpedo could be selectively depleted of the $43,000 M_{\mathrm{r}}$ polypeptide and some other nonAcChoR polypeptides by treatment with base. These treated membranes contained three of the four polypeptides $\left(M_{\mathrm{r}}\right.$ $40,000,50,000$, and 66,000 ) characteristic of the isolated purified AcChoR. These membranes bound a ${ }^{14} \mathrm{C}$-labeled local anesthetic analog specifically, and this was displaced by micromolar concentrations of $\mathrm{H}_{12}$ - $\mathrm{HTX}$.

We report here direct binding of $\left[{ }^{3} \mathrm{H}\right] \mathrm{H}_{12}-\mathrm{HTX}$ to AcChoR-enriched membranes purified by rapid sucrose density gradient centrifugation and then treated with base, as well as stopped-flow kinetics of $\mathrm{H}_{12}$ - $\mathrm{HTX}$ binding by using the fluorescent probe ethidium. The reconstitution of $\left[{ }^{3} \mathrm{H}\right] \mathrm{H}_{12}$ - $\mathrm{HTX}$ binding from cholate extracts of these membranes is also reported. The results indicate that the $43,000 M_{\mathrm{r}}$ polypeptide does not contain the $\mathrm{H}_{12}$-HTX binding site, but rather that specific high-affinity $\mathrm{H}_{12}$-HTX binding is associated with the AcChoR-containing polypeptides of $40,000,50,000,60,000$, and $65,000 M_{\mathrm{r}}$.

\section{MATERIALS AND METHODS}

AcChoR-enriched membrane fragments were prepared from Torpedo californica electroplax by rapid sucrose density gradient fractionation and treated with base (unpublished results). The concentration of ${ }^{125} \mathrm{I}$-labeled $\alpha$-BuTx $\left({ }^{125} \mathrm{I}-\alpha\right.$-BuTx) sites was determined by DEAE-cellulose disc assay (15) using ${ }_{125}$ I- $\alpha$-BuTx prepared from Bungarus multi-cinctus venom (Sigma) by the procedure of Blanchard et al (16). Protein concentrations were measured by the method of Lowry $e t$ al. (17). Cholate (2\%) extracts of the membranes were prepared by stirring the membranes at concentrations of $5-30 \mathrm{mg}$ of protein per $\mathrm{ml}$ for $30 \mathrm{~min}$ at $0^{\circ} \mathrm{C}$ with the detergent followed by centrifugation for $1 \mathrm{hr}$ at $100,000 \times g$.

Abbreviations: AcCho, acetylcholine; AcChoR, acetylcholine receptor; $\alpha$-BuTx, $\alpha$-bungarotoxin; Carb, carbamylcholine; $\mathrm{H}_{12}$-HTX, perhydrohistrionicotoxin. 
$\left[{ }^{3} \mathrm{H}\right] \mathrm{H}_{12}-\mathrm{HTX}$ was prepared and binding to membrane fragments and cholate extracts was measured by centrifugation assay or equilibrium dialysis as described $(5,18)$. Stopped-flow kinetic measurements were performed as described $(19,20)$.

Sodium dodecyl sulfate $/ 8.75 \%$ acrylamide gel electrophoresis was carried out in the buffer system of Laemmli (21). Gels were stained with Coomassie brilliant blue.

\section{RESULTS AND DISCUSSION}

Membrane fragments treated at $\mathrm{pH} 11$ in low-ionic-strength media showed very simple sodium dodecyl sulfate gel electrophoresis patterns. Bands that stained strongly with Coomassie brilliant blue appeared at 40,000,50,000,60,000, and 65,000 $M_{\mathrm{r}}$ [bands identified as subunits of purified AcChoR (11, 22-26)]. Minor components at 90,000 $M_{\mathrm{r}}$ and at apparent molecular weights less than $\mathbf{4 0 , 0 0 0}$ were also present (Fig. 1). No staining was visible at $43,000 M_{\mathrm{r}}$. The specific activity of these preparations was $2-4 \mathrm{nmol}$ of $\alpha$-BuTx sites per mg of protein.

$\left[{ }^{3} \mathrm{H}\right] \mathrm{H}_{12}-\mathrm{HTX}$ bound to the treated membranes lacking the $43,000 M_{\mathrm{r}}$ polypeptide with unchanged stoichiometry and dissociation constant (Fig. 2). The ability of Carb to regulate the affinity of the membranes for $\left[{ }^{3} \mathrm{H}\right] \mathrm{H}_{12}$ - $\mathrm{HTX}$ was unchanged; the $K_{\mathrm{d}}$ for untreated membranes was lowered from $1.4 \mu \mathrm{M}$ to $0.77 \mu \mathrm{M}$ in the presence of $10 \mu \mathrm{M}$ Carb whereas for base-treated membranes it changed from $1.4 \mu \mathrm{M}$ to $0.73 \mu \mathrm{M}$. The values of $K_{\mathrm{d}}$ previously reported for membranes in these buffer conditions (no $\mathrm{Ca}^{2+}$ or $\mathrm{Mg}^{2+}$ present) are $0.9 \mu \mathrm{M}$ in the absence and $0.5 \mu \mathrm{M}$ in the presence of $10 \mu \mathrm{M} \operatorname{Carb}$ (18).

The local anesthetics dibucaine and tetracaine displaced $\left[{ }^{3} \mathrm{H}\right] \mathrm{H}_{12}$-HTX bound to base-treated membranes with apparent $K_{\mathrm{i}} \mathrm{s}$ not significantly different from those determined for untreated membranes (unpublished). The apparent $K_{\mathrm{i}}$ for dibucaine was $60 \mu \mathrm{M}$ and for tetracaine, $2 \mu \mathrm{M}$ (Fig. 3). Carb regulated the affinity of the base-treated membranes for these local anesthetics. Carb $(10 \mu \mathrm{M})$ increased the apparent affinity of the $\mathrm{H}_{12}$-HTX site for dibucaine approximately 17 -fold $\left(K_{\mathrm{i}}=\right.$ $3.5 \mu \mathrm{M})$. The reverse effect was seen with tetracaine; its ap-

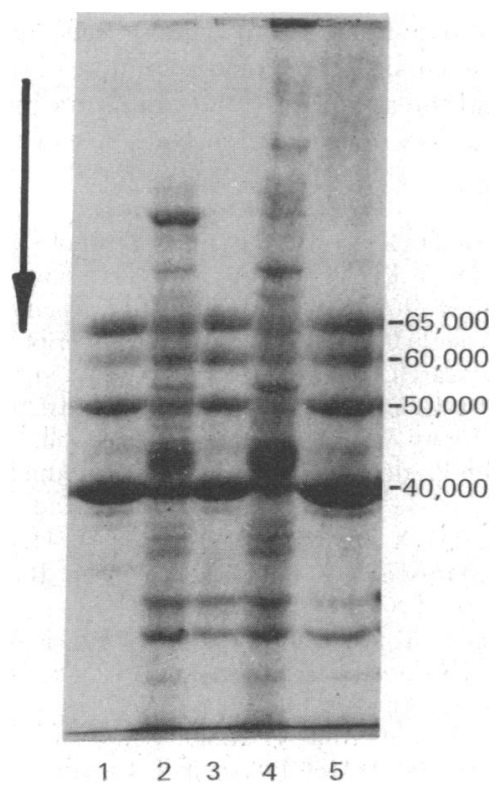

FIG. 1. Sodium dodecyl sulfate/polyacrylamide gel electrophoresis. Lanes: 1 , AcChoR purified by affinity chromatography; 2 , AcChoR-enriched membrane fragments; 3 , AcChoR-enriched membrane fragments treated with base; 4 , the supernatant from base treatment of the membranes; 5 , a $2 \%$ cholate extract of base-treated AcChoRenriched membranes.

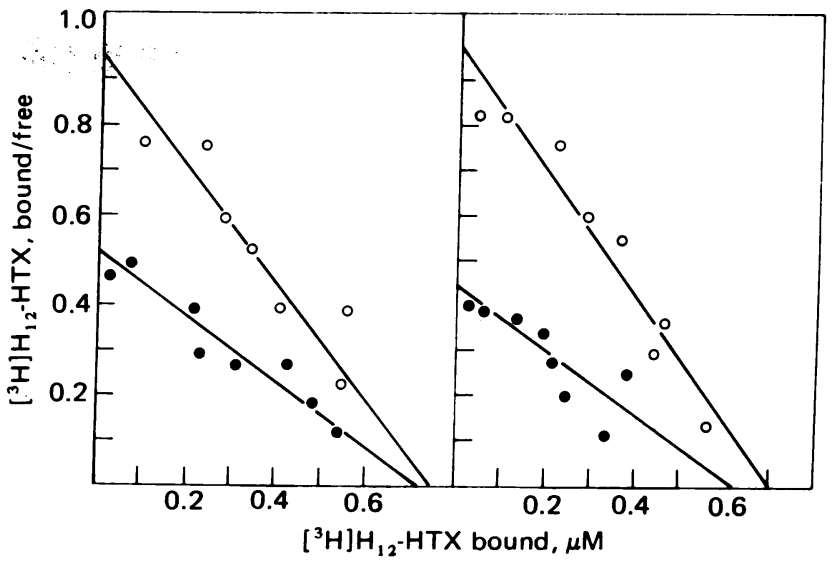

FIG. 2. Scatchard plots of $\left[{ }^{3} \mathrm{H}\right] \mathrm{H}_{12}$ - $\mathrm{HTX}$ binding to AcChoRenriched membranes before (Left) and after (Right) treatment at $\mathrm{pH}$ 11 in the presence $(O)$ and absence $(\bullet)$ of $10 \mu \mathrm{M}$ Carb. In both experiments the concentration of ${ }^{125} \mathrm{I}-\alpha$-BuTx sites was $1.91 \mu \mathrm{M}$ and the buffer was $20 \mathrm{mM}$ Hepes, $\mathrm{pH} 7.4 / 250 \mathrm{mM} \mathrm{NaCl} / 5 \mathrm{mM} \mathrm{KCl} / 0.02 \%$ $\mathrm{NaN}_{3}$. The plots were made by using a linear least-squares fit of the data.

parent affinity was decreased $\approx 1: 30$ in the presence of $10 \mu \mathrm{M}$ $\operatorname{Carb}\left(K_{\mathrm{i}}=60 \mu \mathrm{M}\right)$. It should be noted that at this concentration of Carb the membrane-bound AcChoR was essentially fully converted to the conformational state(s) having high affinity for agonists (27).

The observed kinetics of $\mathrm{H}_{12}$-HTX binding to membranebound AcChoR were unchanged after alkaline extraction of the membrane fragments. Under pseudo-first-order conditions the reaction curve, as monitored by the decay in fluorescence of the extrinsic probe ethidium, was monophasic. The apparent rate constant $\left(k_{\text {app }}\right)$ of this signal change increased with increasing $\mathrm{H}_{12}$-HTX concentration, and rate limitation occurred at high ligand concentrations (Fig. 4). This kinetic behavior is consistent with the mechanism proposed by Schimerlik et al. (7) in which a rapid equilibration of $\mathrm{H}_{12}-\mathrm{HTX}(\mathrm{L})$ and AcChoR $(\mathrm{R})$ is followed by a slow isomerization of the initial complex:

$$
\mathrm{R}+\mathrm{L} \stackrel{K}{\rightleftharpoons} \mathrm{RL} \underset{k_{-1}}{\stackrel{k_{1}}{\rightleftharpoons}} \mathrm{RL}^{*}
$$

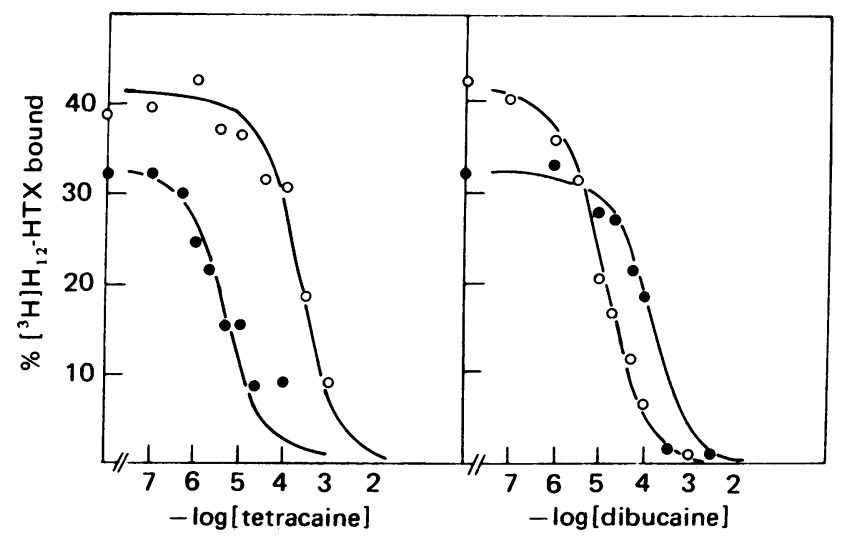

FIG. 3. Displacement of $\left[{ }^{3} \mathrm{H}\right] \mathrm{H}_{12}$-HTX bound to base-treated membranes in the presence $(O)$ and absence $(\bullet)$ of $10 \mu \mathrm{M}$ Carb by tetracaine (Left) and dibucaine (Right). The concentration of ${ }^{125} \mathbf{I}-$ $\alpha$-BuTx sites was $1.33 \mu \mathrm{M}$ and the concentration of $\left[{ }^{3} \mathrm{H}\right] \mathrm{H}_{12}-\mathrm{HTX}$ was $0.44 \mu \mathrm{M}$. The $\left[{ }^{3} \mathrm{H}\right] \mathrm{H}_{12}$-HTX dissociation constants used to draw the theoretical curves for competitive inhibition were $0.2 \mu \mathrm{M}$ in the presence of $10 \mu \mathrm{M}$ Carb and $0.4 \mu \mathrm{M}$ in its absence. The buffer was 20 mM Hepes, pH 7.4/250 mM NaCl/ $5 \mathrm{mM} \mathrm{KCl} / 4 \mathrm{mM} \mathrm{CaCl} 2 / 2 \mathrm{mM}$ $\mathrm{MgCl}_{2} / 0.02 \% \mathrm{NaN}_{3}$. (Left) $\mathrm{O}, K_{\mathrm{i}}=60 \mu \mathrm{M} ; \bullet, K_{\mathrm{i}}=2 \mu \mathrm{M}$. (Right) $\mathrm{O}$, $K_{\mathrm{i}}=3.5 \mu \mathrm{M} ; \bullet, K_{\mathrm{i}}=60 \mu \mathrm{M}$. 


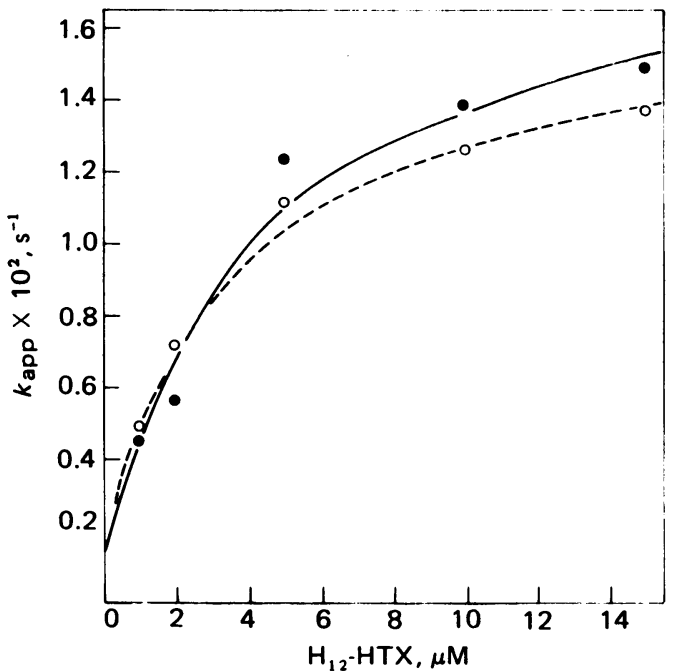

FIG. 4. The effect of $\mathrm{H}_{12}$-HTX concentration on the kinetics of binding of membrane-bound AcChoR before ( $\bullet$ ) and after ( 0 ) base treatment. The final concentration of ${ }^{125} \mathrm{I}-\alpha$-BuTx sites was $0.3 \mu \mathrm{M}$ and of ethidium was $2.0 \mu \mathrm{M}$. The buffer was the same as in Fig. 3 and experiments were carried out at $25^{\circ} \mathrm{C}$. Excitation was at $493 \mathrm{~nm}$ and fluorescence emission was monitored by using a Corning C.S. 3-69 cut-off filter. Each point is the average of at least two determinations, and the lines are those calculated from a nonlinear regression fit to the data, which gave values of $K$ and $k_{1}$ equal to $4.6 \pm 1.0 \mu \mathrm{M}$ (errors given are $\pm \mathrm{SD}$ ) and $0.018 \pm 0.001 \mathrm{~s}^{-1}(\bullet)$ or $3.0 \pm 1.0 \mu \mathrm{M}$ and 0.015 $\pm 0.001 \mathrm{~s}^{-1}(\mathrm{O})$, respectively.

According to such a scheme, the apparent rate constant $k_{\text {app }}$ is given by the relationship:

$$
k_{\text {app }}=\frac{k_{1}[\mathrm{~L}]}{K+[\mathrm{L}]}+k_{-1} \text {. }
$$

The observed concentration dependence of $k_{\text {app }}$ (Fig. 4) was consistent with the relationship, and the values of the kinetic parameters $k_{1}$ and $K$ were obtained from a nonlinear regression fit of the data to the above equation by using the value of $k_{-1}$ equal to $1.5 \times 10^{-3} \mathrm{~s}^{-1}$ estimated by Schimerlik et al. (7). The best fit values of $K$ for the pre-equilibrium and of $k_{1}$ for the isomerization were $4.6 \pm 1.0 \mu \mathrm{M}$ and $0.018 \pm 0.001 \mathrm{~s}^{-1}$, respectively for $\mathrm{H}_{12}$-HTX binding to AcChoR before alkaline extraction, and the corresponding values after treatment were $3.0 \pm 0.7 \mu \mathrm{M}$ and $0.015 \pm 0.001 \mathrm{~s}^{-1}$. These values are in close agreement with those previously reported (7) and they were not significantly affected by variation in the value of $k_{-1}$ between 0 and $3 \times 10^{-3} \mathrm{~s}^{-1}$. It therefore appears that the removal of the $43,000 M_{\mathrm{r}}$ polypeptide does not affect the kinetics of $\mathrm{H}_{12}$-HTX binding to AcChoR-enriched membrane fragments.

Because the 43,000 $M_{\mathrm{r}}$ polypeptide was not necessary for specific binding of $\mathrm{H}_{12}$-HTX, or for binding of the local anesthetics tested, to membrane fragments or for Carb regulation of those binding activities, we investigated the possibility that it has a structural role. We examined this possibility by determining whether $\left.{ }^{3} \mathrm{H}\right] \mathrm{H}_{12}$-HTX binding could be reconstituted after dissolution of the membranes in $2 \%$ cholate (Fig. 5 ). The extract of base-treated membranes was diluted from $2 \%$ to $0.5 \%$ cholate, a concentration at which $\left[{ }^{3} \mathrm{H}\right] \mathrm{H}_{12}$ - $\mathrm{HTX}$ binding was shown to be completely recovered in extracts of untreated membranes (18). The extract bound $\left|{ }^{3} \mathrm{H}\right| \mathrm{H}_{12}-\mathrm{HTX}$ with $K_{\mathrm{d}} \approx$ $2 \mu \mathrm{M}$ and $0.18\left[{ }^{3} \mathrm{H} \mid \mathrm{H}_{12}-\mathrm{HTX}\right.$ sites per ${ }^{125 \mathrm{I}-\alpha} \alpha-\mathrm{BuT} \mathrm{x}$ site. The previously reported $K_{\mathrm{d}}$ and sites ratio for $\left[{ }^{3} \mathrm{H} \mid \mathrm{H}_{12}\right.$-HTX binding to cholate extracts were $1.6 \mu \mathrm{M}$ and 0.26 , respectively (18). Thus, $\left[{ }^{3} \mathrm{H}\right] \mathrm{H}_{12}$-HTX binding was largely, though not com-

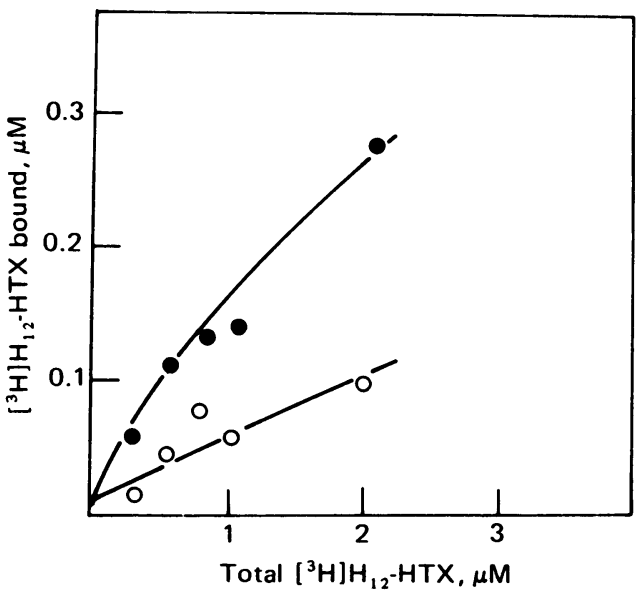

Fig. 5. Binding of $\left[{ }^{3} \mathrm{H}\right] \mathrm{H}_{12}-\mathrm{HTX}$ to a $2 \%$ cholate extract of base-treated membrane fragments diluted to $0.5 \%$ cholate in the presence (O) and absence (๑) of $40 \mu \mathrm{M}$ unlabeled $\mathrm{H}_{12}$-HTX. The concentration of ${ }^{125} \mathrm{I}-\alpha$-BuTx sites was $1.9 \mu \mathrm{M}$. The bottom curve (O) shows a fairly large component of nonspecific binding.

pletely, recovered. The binding of $\left[{ }^{3} \mathrm{H}\right] \mathrm{H}_{12}$ - $\mathrm{HTX}$ to extracts of membranes not treated with base was strongly dependent on cholate concentration (18). It has not yet been shown whether such concentration dependence is the same for base-treated membranes. Thus, the incomplete recovery of $\mathrm{H}_{12}$-HTX binding sites $(\approx 70 \%$ recovered) might be a function of a different dependence on cholate concentration.

\section{CONCLUSIONS}

The results reported here eliminate the possibility that the $43,000 M_{\mathrm{r}}$ polypeptide contains the specific binding site for $\mathrm{II}_{12}$-HTX of $K_{\mathrm{d}} \approx 0.5 \mu \mathrm{M}$ and for some local anesthetics such as dibucaine and tetracaine. Base-treated membranes retain the capacity to bind $\left[{ }^{3} \mathrm{H}\right] \mathrm{H}_{12}-\mathrm{HTX}$ and the local anesthetics tested. The regulation of this binding by Carb and the kinetic mechanism of $\mathrm{H}_{12}-\mathrm{HTX}$ binding are unchanged. Additionally, ${ }^{3} \mathrm{H} \mid \mathrm{H}_{12}$-HTX binding was largely reconstituted from $2 \%$ cholate extracts of base-treated membranes. Thus, the $\mathrm{H}_{12}-\mathrm{HTX}$ binding site appears to be located on one or more of the AcChoR polypeptides, and the reconstitution of that binding site from detergent extracts does not require the presence of a 43,000 $M_{r}$ polypeptide.

$\mathrm{H}_{12}$-HTX and $\mathrm{H}_{8}$-HTX used in the preparation of $\left[{ }^{3} \mathrm{H}\right] \mathrm{H}_{12}$ - $\mathrm{HTX}$ were kind gifts of Dr. Y. Kishi, who produced them synthetically (28, 29). Thanks are due to John Racs for help with Torpedo membrane preparations and Valerie Purvis for typing the manuscript and drawing the figures. This research was supported by grants from the National Institutes of Health (U.S. Public Health Service NS 10294) and from the Muscular Dystrophy Association of America, as well as by National Institutes of Health Predoctoral Fellowships to J.E. and S.G.B.

1. Albuquerque, E. X., Barnard, E. A., Chiu, T. H., Lapa, A. J., Dolly, J. O., Jansson, S.-E., Daly, J. \& Witkop, B. (1973) Proc. Natl. Acad. Sci. USA 70, 949-953.

2. Albuquerque, E. X., Kuba, K., Lapa, A. J., Daly, J. W. \& Witkop B. (1973) in Exploratory Concepts in Muscular Dystrophy II, (Excerpta Med., Amsterdam), pp. 585-597.

3. Dolly, J. O., Albuquerque, E. X., Sarvey, J. M., Mallick, B. \& Barnard, E. A. (1977) Mol. Pharmacol. 13, 1-14.

4. Kato. G. \& Changeux, J.-P. (1976) Mol. Pharmacol. 12, 92100.

5. Elliott, J. \& Raftery, M. A. (1977) Biochem. Biophys. Res. Commun. 77, 1347-1353.

6. Burgermeister, W. Catterall, W. \& Witkop, B. (1977) Proc. Natl. Acad. Sci. USA 74, $5754-5758$ 
7. Schimerlik, M. I., Quast, U. \& Raftery, M. A. (1979) Biochemistry, in press.

8. Schmidt, J. \& Raftery, M. A. (1973) Biochemistry 12, 852856.

9. Moody, T., Schmidt, J. \& Raftery, M. A. (1973) Biochem. Biophys. Res. Commun. 53, 761-772.

10. Martinez-Carrion, M. \& Raftery, M. A. (1973) Biochem. Biophys. Res. Commun. 55, 1156-1164.

11. Raftery, M. A., Vandlen, R. L., Reed, K. L. \& Lee, T. (1975) Cold Spring Harbor Symp. Quant. Biol. 40, 193-202.

12. Sobel, A., Heidmann, T., Hofler, J. \& Changeux, J.-P. (1978) Proc. Natl. Acad. Sci. USA 75, 510-514.

13. Eldefrawi, A. T., Eldefrawi, M. E., Albuquerque, E. X., Oliveira, A. C., Mansour, N., Adler, M., Daly, J., Brown, G., Burgermeister, W. \& Witkop, B. (1977) Proc. Natl. Acad. Sci. USA 74, 2172 2176

14. Neubig, R. R., Krodel, E. K., Cohen, J. B. (1978) Abstr. Soc. Neurosci. Annu. Meet., Abstr. 1658, 8, 517.

15. Schmidt, J. \& Raftery, M. A. (1973) Anal. Biochem. 52, 349354.

16. Blanchard, S. G., Quast, U., Reed, K., Lee, T., Schimerlik, M. I., Vandlen, R., Claudio, T., Strader, C. D., Moore, H.-P. \& Raftery, M. A. (1979) Biochemistry, in press.

17. Lowry, O. H., Rosebrough, N. J., Farr, A. L. \& Randall, R. J. (1951) J. Biol. Chem. 193, 265-275.

18. Elliott, J. \& Raftery, M. A. (1979) Biochemistry, in press.
19. Quast, U., Schimerlik, M. \& Raftery, M. A. (1978) Biochem. Biophys. Res. Commun. 81, 955-964.

20. Schimerlik, M. I., Quast, U. \& Raftery, M. A. (1979) Biochemistry, in press.

21. Laemmli, U. K. (1970) Nature (London) 227, 680-685.

22. Raftery, M. A., Bode, J., Vandlen, R., Chao, Y., Deutsch, J., Duguid, J. R., Reed, K. \& Moody, T. (1974) in Biochemistry of Sensory Functions, ed. Jaenicke, L. (Springer, New York), pp. 541-564.

23. Weill, C. L., McNamee, M. G. \& Karlin, A. (1974) Biochem. Biophys. Res. Commun. 61, 997-1003.

24. Karlin, A., Weill, C. L., McNamee, M. G. \& Valderamma, R. (1975) Cold Spring Harbor Symp. Quant. Biol. 40, 203-210.

25. Vandlen, R. L., Schmidt, J. \& Raftery, M. A. (1976) J. Macromol. Sci. Chem. Al0, 73-109.

26. Vandlen, R. L., Wu, W. C.-S., Eisenach, J. \& Raftery, M. A. (1979) Biochemistry, in press.

27. Quast, U., Schimerlik, M. I., Lee, T., Witzemann, V., Blanchard, S. \& Raftery, M. A. (1978) Biochemistry 12, 2405-2414.

28. Aratani, M., Dunkerton, L. V., Fukuyama, T., Kishi, Y., Kakoi, H., Sugiura, S. \& Inoue, S. (1975) J. Org. Chem. 40, 20092011

29. Fukuyama, T., Dunkerton, L. V., Aratani, M. \& Kishi, Y. (1975) J. Org. Chem. 40, 2011-2012. 